\title{
Fair Plan 6: Quo Vadis the 80\%-Emission-Reduction-By-2050 Plan?
}

\author{
Michael E. Schlesinger, Michael Ring, Emily Cross \\ Climate Research Group, Department of Atmospheric Sciences, University of Illinois at Urbana-Champaign, \\ Urbana, USA \\ Email: schlesin@illinois.edu
}

Received 6 April 2015; accepted 20 April 2015; published 29 April 2015

Copyright (C) 2015 by authors and Scientific Research Publishing Inc.

This work is licensed under the Creative Commons Attribution International License (CC BY).

http://creativecommons.org/licenses/by/4.0/

(c) (i) Open Access

\begin{abstract}
In our Fair Plan 5 paper, we compared the $\mathrm{CO}_{2}$ emissions of the 80\%-Emission-Reduction-By-2050 $(80 / 50)$ Plan with the $\mathrm{CO}_{2}$ emissions of our Fair Plan to Safeguard Earth's Climate. We found that the 80/50 Plan reduced $\mathrm{CO}_{2}$ emissions more rapidly than necessary to achieve the principal objective of the Fair Plan: to keep Global Warming (GW) within the $2^{\circ} \mathrm{C}\left(3.6^{\circ} \mathrm{F}\right)$ limit adopted by the UN Framework Convention on Climate Change (UNFCCC) "to prevent dangerous anthropogenic interference with the climate system". Here, we ask the "What If" question: "What would the GW of the 80/50 Plan be post 2100 if its $\mathrm{CO}_{2}$ emissions post 2100 were kept at their 2100 value?" We find that although the GW of the 80/50 Plan decreases slightly over part of the 21st century, it does not remain constant thereafter. Rather, the GW of the 80/50 Plan begins to increase in 2088, exceeds that of the Fair Plan beginning in 2230, exceeds the $2^{\circ} \mathrm{C}\left(3.6^{\circ} \mathrm{F}\right)$ limit of the UNFCCC in 2596 , and ends the millennium at $2.7^{\circ} \mathrm{C}\left(4.8^{\circ} \mathrm{F}\right)$. Thus, not only does the 80/50 Plan phase out humanity's $\mathrm{CO}_{2}$ emissions faster than necessary to fulfill the UNFCCC constraint, it also fails that constraint if its $\mathrm{CO}_{2}$ emissions post 2100 are kept at their 2100 value. Accordingly, we believe that the Fair Plan to Safeguard Earth's Climate is superior to the 80/50 Plan.
\end{abstract}

\section{Keywords}

Climate Change, Global Warming, Greenhouse-Gas Emissions, Mitigation

\section{Introduction}

In our Fair Plan 5 paper [1], we compared and contrasted the greenhouse-gas emissions of the 80\%-EmissionReduction-By-2050 (80/50) Plan with both our Fair Plan to Safeguard Earth's Climate and a Reference case. The $\mathrm{CO}_{2}$ emissions of these three scenarios are shown in Figure 1 and are described below. 


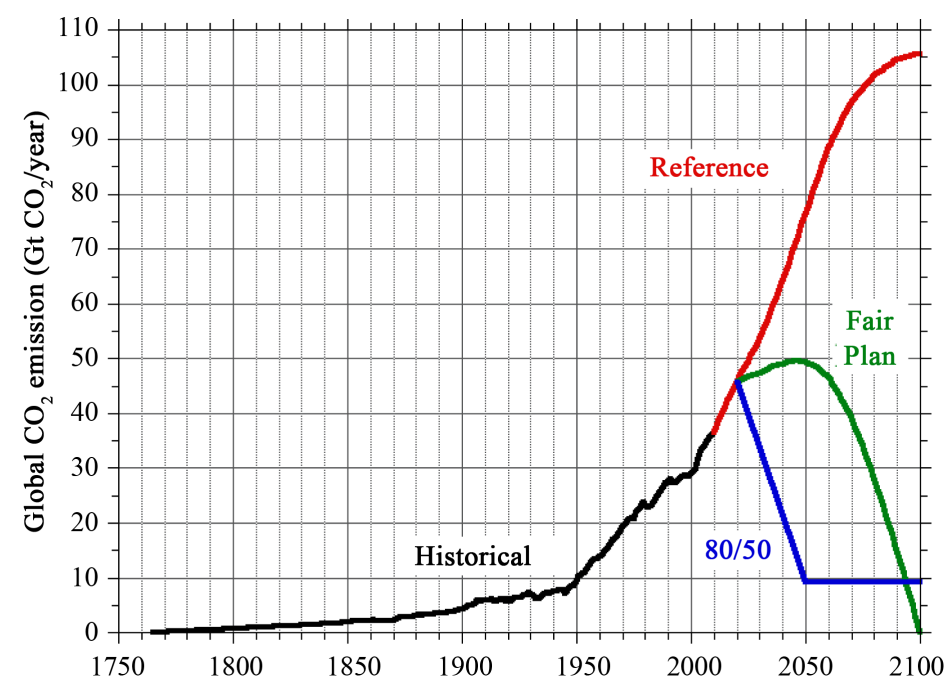

Figure 1. $\mathrm{CO}_{2}$ emissions from 1750 to 2100: Historical (black line), Reference case (red line), Fair Plan to Safeguard Earth's Climate (green line), and the 80/50 Plan (blue line).

\subsection{Reference Case}

In our five earlier Fair Plan papers, FP1 - FP5 [1]-[5], we have taken the Reference Concentration Plan 8.5 (RCP-8.5) greenhouse gas (GHG) emission scenario [6] as our Reference case, which is the way the world would likely emit GHGs if either there were no consequent climate change or if we were completely ignorant thereof. The RCP-8.5 was developed at the International Institute for Applied Systems Analysis near Vienna, Austria, to be one of four emission scenarios developed for the Fifth Assessment Report (AR5) of the Intergovernmental Panel on Climate Change (IPCC) [7]. RCP-8.5 is the highest of these scenarios and leads to a radiative forcing - the change in the net incoming radiation at the top of Earth's atmosphere — of about $8.5 \mathrm{~W} \cdot \mathrm{m}^{-2}$ in 2100. The emission of $\mathrm{CO}_{2}$ under RCP-8.5 is shown by the red line in Figure 1.

\subsection{Fair Plan to Safeguard Earth's Climate}

We crafted the Fair Plan to Safeguard Earth's Climate [3] to achieve three objectives:

Objective 1: The cumulative trade-adjusted $\mathrm{CO}_{2}$ emissions by the developing countries equal the cumulative trade-adjusted $\mathrm{CO}_{2}$ emissions by the developed countries. Trade-adjusted emissions mean the emissions incurred by country A to export goods and/or services to country B are debited to country B, not country A.

Objective 2: The maximum Global Warming above preindustrial temperature does not exceed the $2^{\circ} \mathrm{C}\left(3.6^{\circ} \mathrm{F}\right)$ chosen by the United Nations Framework Convention on Climate Change (UNFCCC) "to prevent dangerous anthropogenic interference with the climate system" [8].

Objective 3: The phaseout of $\mathrm{CO}_{2}$ emissions is begun as late as possible in the 21 st century and proceeds at the slowest possible pace, consistent with Objectives 1 and 2.

The trade-adjusted $\mathrm{CO}_{2}$ emissions by the developed countries are taken as the product of the $\mathrm{CO}_{2}$ emissions of the Reference case times an intensity that linearly decreases in time from unity in 2020 to zero in 2100 . Similarly, the trade-adjusted $\mathrm{CO}_{2}$ emissions by the developing countries are taken as the product of the $\mathrm{CO}_{2}$ emissions of the Reference case times an intensity that decreases in time more slowly than linearly from unity in 2020 to zero in 2100 . The intensity for the developing countries is a cubic polynomial in time with the coefficients set to achieve Objectives 1 and 2 above. The emission of $\mathrm{CO}_{2}$ under the Fair Plan is shown by the green line in Figure 1. For the emissions of the other greenhouse gases, we took their curves from RCP-8.5 and applied the same intensities thereto for the developed and developing countries as we did for $\mathrm{CO}_{2}$. Further details of these calculations are described in FP2 [3].

\subsection{0/50 Plan}

In the $80 / 50$ Plan, greenhouse-gas emissions are reduced by $80 \%$ relative to a reference year - taken here to be 
2020 - by 2050 and are then held constant throughout the remainder of the 21 st century as shown by the blue line in Figure 1. The likely origin and history of the 80/50 Plan are described in FP5 [1]. The 80/50 Plan has been proposed as the emission reduction plan for the United States in H.R.5271, the Healthy Climate and Family Security Act of 2014 [9]. The 80/50 Plan was also implicit in the emission reduction cited in the White House press release of 11 November 2014 about the U.S.-China Joint Announcement on Climate Change and Clean Energy Cooperation [7].

In FP5 [1], we compared the $\mathrm{CO}_{2}$ emissions of the 80/50 Plan with the emissions of the Fair Plan and the Reference case through the 21st century, which is shown in Figure 1. We found that the 80/50 Plan reduces greenhouse-gas emissions much more rapidly than necessary to achieve Objective 2 above, which Objective our Fair Plan to Safeguard Earth's Climate achieves.

Here, we extend our analysis through the third millennium and examine not only the $\mathrm{CO}_{2}$ emissions, but also the $\mathrm{CO}_{2}$ concentrations and the changes in global-mean near-surface air temperature, that is, the Global Warming (GW). To our knowledge, this is the first time that the GW of the 80/50 Plan has been considered beyond 2100 .

\section{Carbon Dioxide $\left(\mathrm{CO}_{2}\right)$}

In this section we discuss the $\mathrm{CO}_{2}$ emissions and concentrations, and the carbon budgets of the Reference case, the Fair Plan to Safeguard Earth's Climate, and the 80/50 Plan.

\subsection{Emissions}

The $\mathrm{CO}_{2}$ emissions through the third millennium are shown in Figure 2. As in FP1 - FP5 [1]-[5], the Reference case from 2101 to 2500 is the Extended Concentration Pathway 8.5 (ECP-8.5) [10]. Thereafter, through 3000, the emission rate is kept equal to its value in 2500. In contrast, by design, the $\mathrm{CO}_{2}$ emissions for the Fair Plan are zero post 2100 . To our knowledge, post- $2100 \mathrm{CO}_{2}$ emissions for the $80 / 50$ Plan have not been proposed. Accordingly, here we examine the "What If" question: "What would the post-2100 GW be if the post- $2100 \mathrm{CO}_{2}$ emissions were kept at their 2100 value?"

\subsection{Concentrations}

We use the simple carbon-cycle model of the Center for International Climate and Environmental ResearchOslo (CICERO) [11] to calculate the $\mathrm{CO}_{2}$ concentrations from the $\mathrm{CO}_{2}$ emissions (Figure 3). It should be noted that this model does not include the positive ocean- $\mathrm{CO}_{2}$-solubility/temperature feedback whereby the fraction of

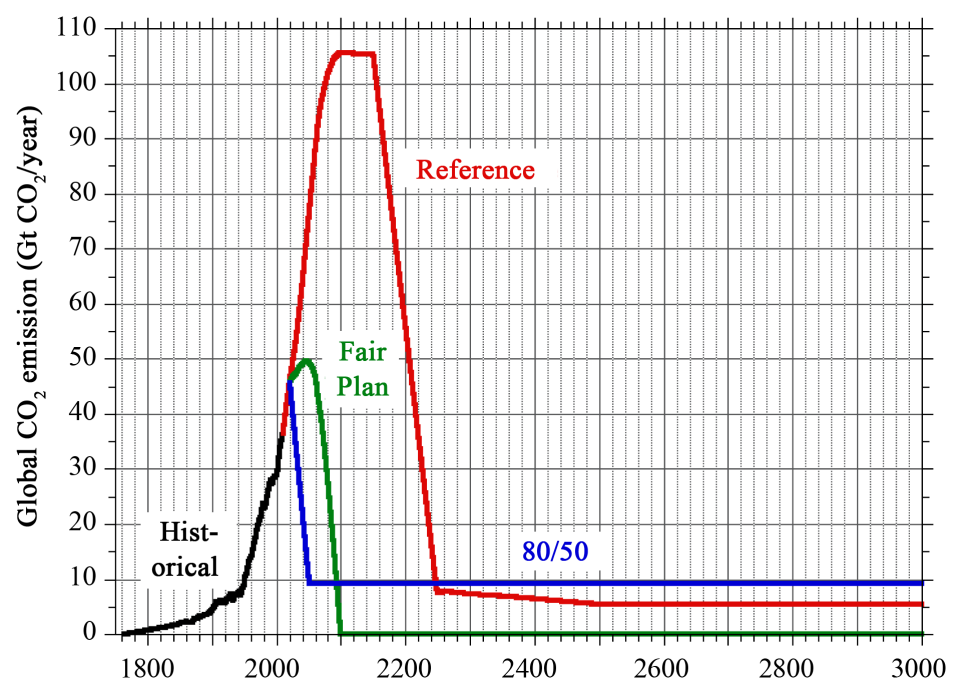

Figure 2. $\mathrm{CO}_{2}$ emissions from 1750 to 3000 : Historical (black line), Reference case (red line), Fair Plan to Safeguard Earth's Climate (green line), and the 80/50 Plan (blue line). 


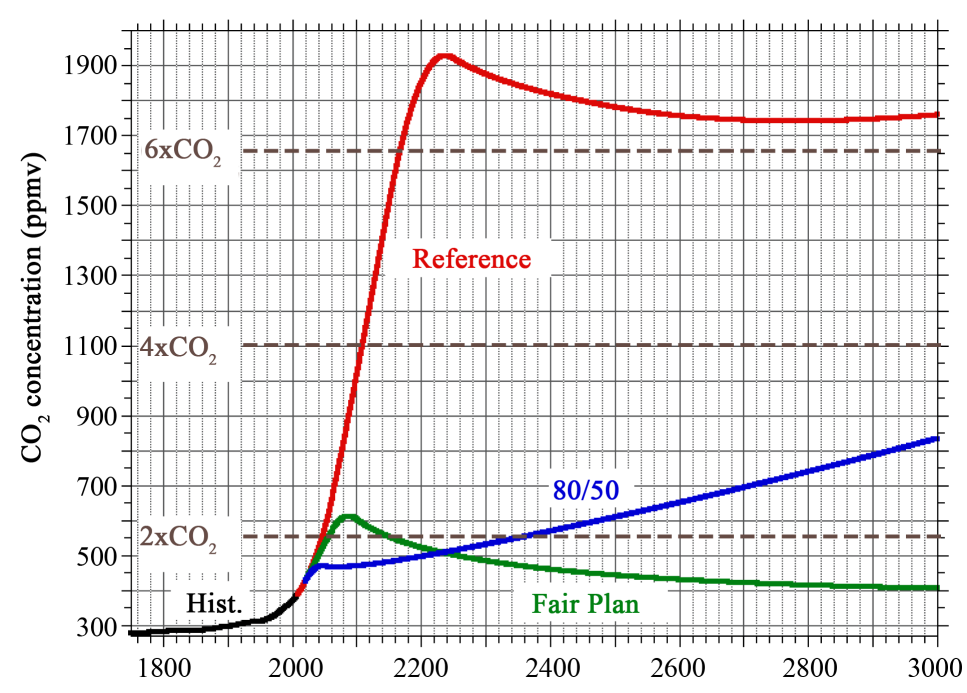

Figure 3. $\mathrm{CO}_{2}$ concentrations from 1750 to 3000: Historical (black line), Reference case (red line), Fair Plan to Safeguard Earth's Climate (green line), and the 80/50 Plan (blue line). The dashed brown lines show the $\mathrm{CO}_{2}$ concentrations equal to twice $\left(2 \mathrm{xCO}_{2}\right)$, four times $\left(4 \mathrm{xCO}_{2}\right)$, and six times $\left(6 \mathrm{xCO}_{2}\right)$ the pre-industrial concentration $(277 \mathrm{ppmv})$.

emitted $\mathrm{CO}_{2}$ removed from the atmosphere by the ocean decreases with increasing temperature. Thus, ceteris paribus, our calculated $\mathrm{CO}_{2}$ concentrations are underestimates of those with this positive feedback included.

For the Reference case, the $\mathrm{CO}_{2}$ concentration rises to $1928 \mathrm{ppmv}$ in 2237 and then, as a result of the natural sinks (Section 2.3), decreases to about 1750 ppmv over the last 400 years of the third millennium. Figure 4, based on the data of [12], shows that this is about 500 ppmv larger than the $\mathrm{CO}_{2}$ concentration was during the late Eocene, 35 million years ago. Then there was no ice on Earth and sea level was 73 meters (240 feet) higher than at the beginning of the Industrial Revolution. Some of the coastal cities of the World that would be inundated by a sea-level rise of 66 meters (216 feet), based on a study by the National Geographic Society [13], are listed in Table 1. Clearly, this is an outcome that humanity should not create by continuing its unabated emission of greenhouse gases.

For the Fair Plan, the $\mathrm{CO}_{2}$ concentration rises to $612 \mathrm{ppmv}$ in 2087, a bit more than twice the pre-industrial $\mathrm{CO}_{2}$ concentration of $554 \mathrm{ppmv}$, and then decreases to $406 \mathrm{ppmv}$ by the end of the third millennium.

For the 80/50 Plan, the $\mathrm{CO}_{2}$ concentration remains approximately constant throughout the 21 st century, with a mean value of 463 ppmv. Indeed, as we explained in FP5 [1], it is because of this near constancy of the $\mathrm{CO}_{2}$ concentration throughout this century that the 80/50 Plan has been proposed. But if the $\mathrm{CO}_{2}$ emission of the 80/ 50 Plan is continued beyond the 21 st century at its value in 2100 , the $\mathrm{CO}_{2}$ concentration ceases to remain constant and instead increases throughout the millennium to $834 \mathrm{ppmv}$ in year 3000, nearly three times the pre-industrial value. Below we examine the carbon budget to learn how this happens.

\subsection{Carbon Budgets}

The carbon budgets are shown in Figure 5 for the Reference case (panel (a)), Fair Plan (panel (b)) and 80/50 Plan (panel (c)). In each panel the anthropogenic source, $E_{A}$, is shown by the red solid line; the total sink, $S_{T}=S_{O}+S_{B}$, is shown by the purple solid line-with the oceanic sink $S_{O}$ and biological sink $S_{B}$ shown by the thin blue and green dashed lines, respectively; the net emission, $E_{N}=E_{A}-S_{T}$, is shown by the black solid line (note that, for clarity, the vertical scale for panels (b) and (c) is different from the vertical scale for panel (a)).

For each scenario, $E_{N}$ decreases to below zero in the wake of the reduction in the anthropogenic source, $E_{A}$. This occurs in 2239, 2089 and 2048 for the Reference case, Fair Plan and 80/50 Plan, respectively. $E_{N}$ remains below or near zero for the Reference case and Fair Plan, but not for the 80/50 Plan. For the latter, $E_{N}$ becomes positive in 2071 and steadily increases to almost $4 \mathrm{Gt} \mathrm{CO}_{2} /$ year by the end of the millennium. It is this difference in behavior of $E_{N}$ for the 80/50 Plan that leads to the increase in $\mathrm{CO}_{2}$ concentration after the 21st 


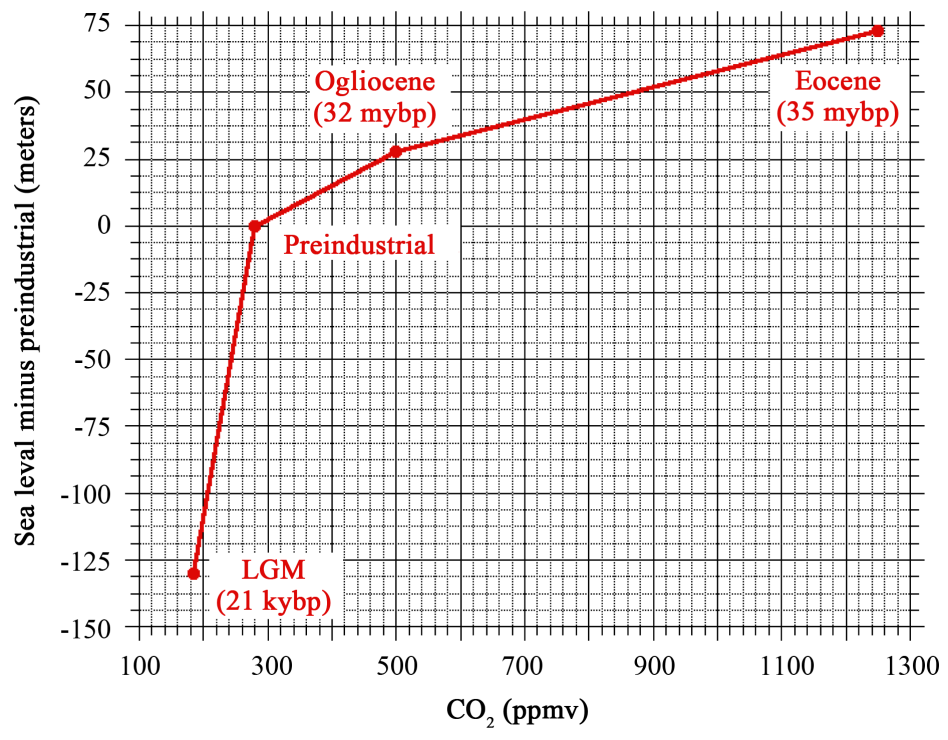

Figure 4. Sea level relative to pre-industrial sea level versus $\mathrm{CO}_{2}$ concentration for past climates: the Last Glacial Maximum (LGM) 21,000 years before present $(21 \mathrm{kbp})$, the Oligocene 32 million years before present (32 $\mathrm{mbp}$ ) and the Eocene 35 million years before present $(35 \mathrm{mbp})$ based on the data of [12].
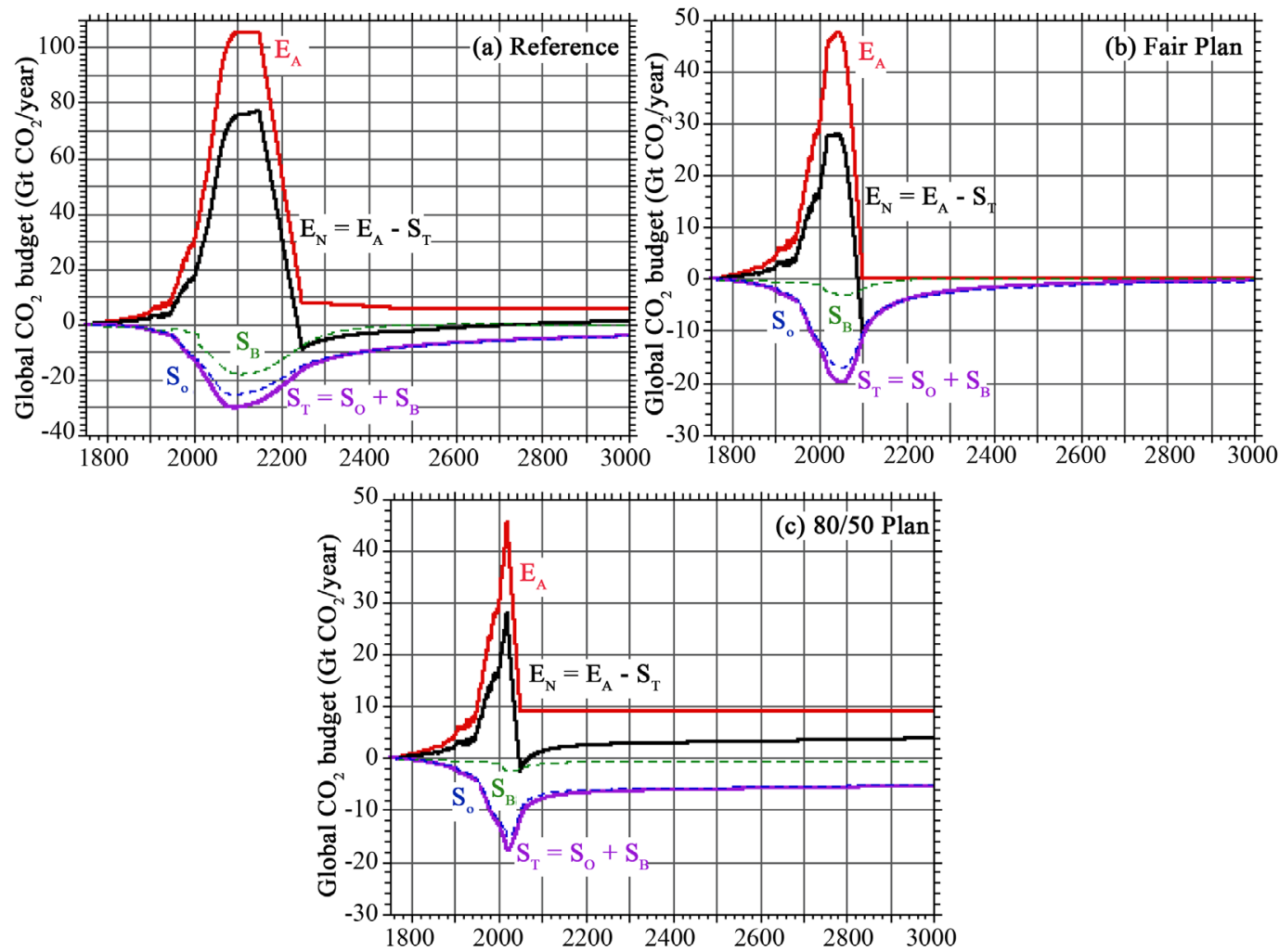

Figure 5. $\mathrm{CO}_{2}$ budget for the Reference case (panel (a)), Fair Plan (panel (b)) and 80/50 Plan (panel (c)). In each panel the anthropogenic source, $E_{A}$, is shown by the red solid line; the total sink, $S_{T}=S_{O}+S_{B}$, is shown by the purple solid line-with the oceanic and biological sinks, $S_{O}$ and $S_{B}$, shown by the thin blue and green dashed lines, respectively; and the net emission, $\mathrm{E}_{\mathrm{N}}=\mathrm{E}_{\mathrm{A}}-\mathrm{S}_{\mathrm{T}}$, is shown by the black solid line (note that, for clarity, the vertical scale for panels (b) and (c) is different from the vertical scale for panel (a)). 
Table 1. Some of the world's cities inundated by a sea-level rise of 66 meters (216 feet). These data are based on a study by the National Geographic Society [13].

\begin{tabular}{cl}
\hline \multicolumn{1}{c}{ Region } & \multicolumn{1}{c}{ Coastal Cities Inundated } \\
\hline North America \& Gulf of Mexico & $\begin{array}{l}\text { Cancún, Veracruz, Havana, Houston, New Orleans, Miami, Tampa, Charleston, Norfolk, } \\
\text { Washington DC, New York, Boston, San Diego }\end{array}$ \\
Western Europe & $\begin{array}{l}\text { London, Brussels, Amsterdam, Copenhagen, Stockholm, Helsinki, St. Petersburg, Tallinn, } \\
\text { Riga }\end{array}$ \\
Mediterranean \& Black Seas & $\begin{array}{l}\text { Venice, Istanbul, Odessa } \\
\text { Red Sea \& India }\end{array}$ \\
Southeast Asia & $\begin{array}{l}\text { Dhaka, Yangon (Rangoon), Bangkok, Kuala Lumpur, Jakarta, Singapore, Phnom Penh, Ho } \\
\text { Chi Minh City }\end{array}$ \\
East Asia & Manila, Hong Kong, Shanghai, Beijing, Seoul, Tokyo \\
South America & Lima, Asuncion, Montevideo, Rio de Janeiro \\
Africa & Dakar, Freetown Monrovia, Lagos, Luanda, Maputo, Dar es Salaam \\
Australia \& New Zealand & Perth, Adelaide, Melbourne, Sydney, Brisbane, Auckland, Wellington
\end{tabular}

century shown in Figure 3.

For the Reference case, $S_{T}$ following the decrease of $E_{A}$ to about $6 \mathrm{Gt} \mathrm{CO}_{2} /$ year, is nearly equal to $E_{A}$, hence, the post-phase-down $\mathrm{E}_{\mathrm{N}}$ is nearly zero. For the Fair Plan, $E_{A}$ is zero after 2100; hence $S_{T}$ thereafter causes the post-phase-down $\mathrm{E}_{\mathrm{N}}$ to be negative. But for the 80/50 Plan, $S_{T}$ following the decrease of $E_{A}$ to

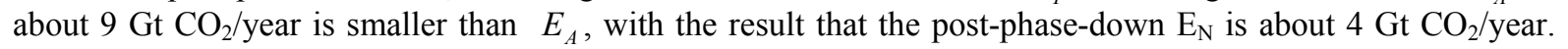
This is caused, in part, by the smallness of the biological sink, $S_{B}$. From this it appears that the rapid phase-out period for the 80/50 Plan is just too fast for the natural $\mathrm{CO}_{2}$ sinks to keep pace with the post-phase-down $E_{A}$. Thus it would be interesting to examine how the result for the 80/50 Plan would change if the phase-down period were increased from 30 years (2020 to 2050) to a longer period, and/or if the post-phase-down $E_{A}$ were decreased to below $9 \mathrm{Gt} \mathrm{CO}_{2}$ /year. But the Fair Plan does exactly this, as it was designed to do, namely increase the phase-down period to its longest possible value consistent with Objectives 1 and 2 of Section 1.2-thus yielding 80 years (2020 to 2100 ) — and the post-phase-down $E_{A}$ to zero.

\section{Global Warming}

We have used the CICERO emission-to-concentration model [14] to calculate the concentrations of the longlived greenhouse gases from their emissions. The radiative-forcing factors considered herein are shown in Table 2. We have used our engineering climate model [15] to calculate the change in global-mean near-surface air temperature (Global Warming) for the Reference case, the Fair Plan to Safeguard Earth's Climate and the 80/50 Plan, each for the four climate sensitivities-the equilibrium $\mathrm{GW}$ for a doubling of the pre-industrial $\mathrm{CO}_{2}$ concentration, $\Delta T_{2 x}$-that we obtained in our 2012 Causes paper [16], one for each of the four observational temperature datasets: 1) the Hadley Centre/Climate Research Unit, $\left.\Delta T_{2 x}=1.61{ }^{\circ} \mathrm{C} ; 2\right)$ NOAA, $\left.\Delta T_{2 x}=1.99{ }^{\circ} \mathrm{C} ; 3\right) \mathrm{NASA}$, $\Delta T_{2 x}=1.45^{\circ} \mathrm{C}$; 4 ) the Japanese Meteorological Agency (JMA), $\Delta T_{2 x}=2.01^{\circ} \mathrm{C}$. The expected value of the GW is taken as the arithmetic average of the GW for these four climate sensitivities.

Figure 6 presents the historical GW (black line) and the expected GW for the Reference case (red line), the Fair Plan to Safeguard Earth's Climate (green line), and the 80/50 Plan (Blue line). The UNFCCC limit of $2^{\circ} \mathrm{C}$ $\left(3.6^{\circ} \mathrm{F}\right)$ "to prevent dangerous anthropogenic interference with the climate system" is shown by the dashed brown line.

The GW for the Reference case increases to $5.2^{\circ} \mathrm{C}\left(9.4^{\circ} \mathrm{F}\right)$ in 2225 and remains within $0.1^{\circ} \mathrm{C}\left(0.2^{\circ} \mathrm{F}\right)$ thereof throughout the remainder of the millennium, that is, for almost 40 human generations. With this level of GW it is likely that all ice on Earth would melt, thereby raising sea level 73 meters (240 feet) (Figure 4) and inundating many of the World's cities (Table 1).

The GW for the Fair Plan peaks at $2.04^{\circ} \mathrm{C}\left(3.7^{\circ} \mathrm{F}\right)$ in 2082 , just above the $2^{\circ} \mathrm{C}\left(3.6^{\circ} \mathrm{F}\right) \mathrm{UNFCCC}$ limit, and decreases throughout the remainder of the millennium to $0.9^{\circ} \mathrm{C}\left(1.6^{\circ} \mathrm{F}\right)$ in year 3000 .

The GW for the $80 / 50$ Plan decreases from $1.45^{\circ} \mathrm{C}\left(2.61^{\circ} \mathrm{F}\right)$ in 2048 to $1.31^{\circ} \mathrm{C}\left(2.36^{\circ} \mathrm{F}\right)$ in 2087 , and increases 
Table 2. Radiative-forcing factors.

\begin{tabular}{|c|c|c|}
\hline Greenhouse Gases & Aerosols & Other \\
\hline $\begin{array}{c}\mathrm{CO}_{2}, \mathrm{CH}_{4}, \mathrm{~N}_{2} \mathrm{O}, \mathrm{CFC} 11, \mathrm{CFC} 12, \mathrm{CFC} 113, \mathrm{CFC} 114, \mathrm{CFC} 115, \mathrm{CCl}_{4}, \\
\mathrm{CH}_{3} \mathrm{CCl} \mathrm{Cl}_{3}, \mathrm{HCFC} 22, \mathrm{HCFC} 141 \mathrm{~b}, \mathrm{HCFC} 123, \mathrm{HCFC} 124, \mathrm{HCFC} 142 \mathrm{~b}, \\
\mathrm{HCFC}_{2} 25 \mathrm{ca}, \mathrm{HCFC} 225 \mathrm{cb}, \mathrm{HCFC} 134 \mathrm{a}, \mathrm{HCFC} 125, \mathrm{HCFC} 152 \mathrm{a}, \mathrm{CF}_{4}, \\
\mathrm{C}_{2} \mathrm{~F}_{6}, \mathrm{SF}_{6}, \mathrm{H} 1211, \mathrm{H} 1301, \mathrm{H} 2402, \mathrm{CH}_{3} \mathrm{Br}, \mathrm{HFC} 23, \mathrm{HFC} 143 \mathrm{a}, \mathrm{HFC} 32, \\
\text { HFC227, HFC245, } \mathrm{C}_{6} \mathrm{~F}_{14}, \text { Tropospheric } \mathrm{O}_{3}\end{array}$ & $\begin{array}{l}\mathrm{SO}_{2} \text {, black carbon, } \\
\text { organic carbon }\end{array}$ & $\begin{array}{l}\text { Solar irradiance variations, } \\
\text { volcanoes, land-use changes }\end{array}$ \\
\hline
\end{tabular}

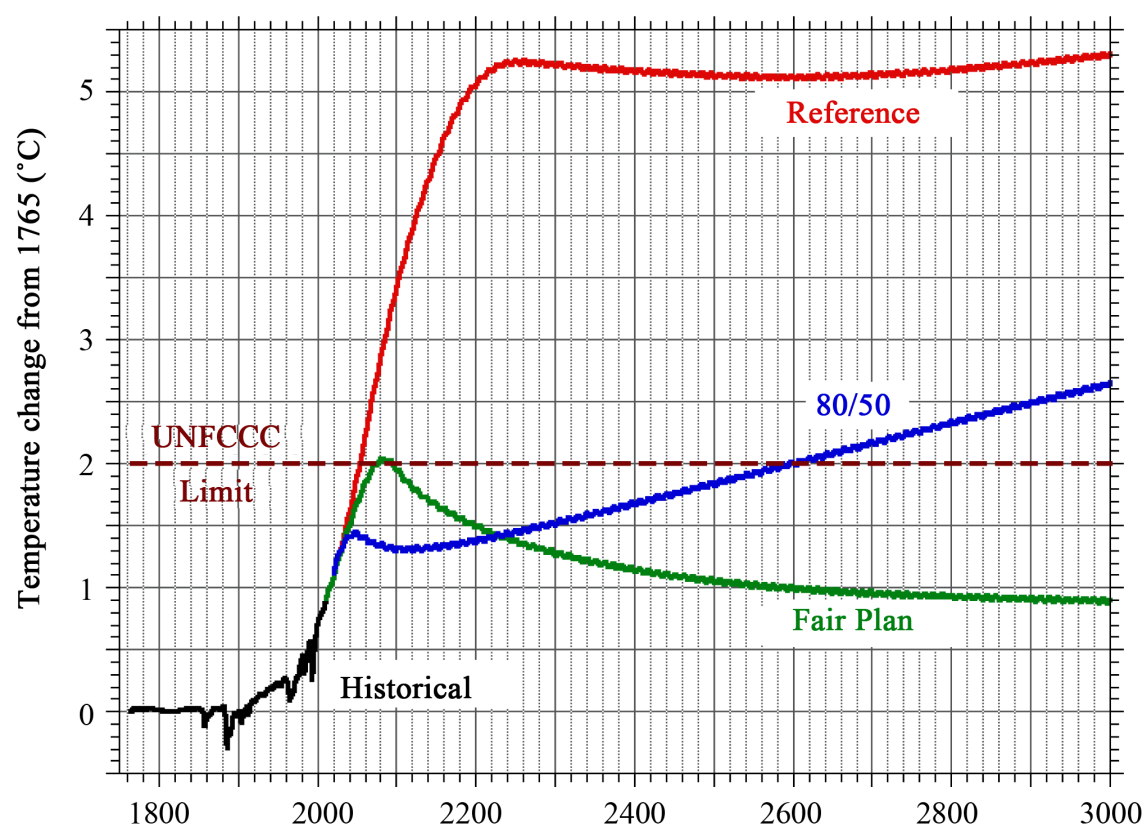

Figure 6. The change in global-mean near-surface temperature from 1765 (Global Warming) from 1765 to 3000: Historical (black line), Reference case (red line), Fair Plan to Safeguard Earth's Climate (green line), and the 80/50 Plan (blue line). The UN Framework Convention on Climate Change (UNFCCC) limit of $2^{\circ} \mathrm{C}$ is shown by the dashed brown line.

thereafter. This decrease in the $\mathrm{GW}$ is due to 1) the rapid decrease in methane emission from 2020 to 2050 (Figure 7(a)), 2) the $8.7 \pm 1.3$ year lifetime of methane in the Earth's atmosphere [17] (page 541), both of which cause a rapid decrease in the methane concentration (Figure 7(b)), and 3) methane's high global-warming potential-72 on a 20-year timescale [17] (Table 2.14, p. 212). The GW for the 80/50 Plan exceeds that for the Fair Plan beginning in 2230 , exceeds the UNFCCC $2^{\circ} \mathrm{C}\left(3.6^{\circ} \mathrm{F}\right) \mathrm{GW}$ limit in 2596 , and rises to $2.7^{\circ} \mathrm{C}\left(4.8^{\circ} \mathrm{F}\right)$ in year 3000 .

\section{Conclusion}

To our knowledge, the GW of the 80/50 Plan has not previously been examined beyond the 21st century. Here, we have examined this for the "What If" scenario that the $80 / 50$ GHG emissions are continued beyond the 21st century at their values in 2100 . We find that in this case the GW of the 80/50 Plan bottoms out in 2087 and rises thereafter, eventually crossing the declining GW of the Fair Plan in 2230. The putative GHGs emissions of the $80 / 50$ Plan cause its GW to exceed the UNFCCC GW limit of $2^{\circ} \mathrm{C}\left(3.6^{\circ} \mathrm{F}\right)$ in 2596 and reach $2.7^{\circ} \mathrm{C}$ in 3000 . Of course, reducing its post-2100 GHG emissions to below their 2100 values can change this GW behavior of the 80/50 Plan. But the lower the emissions of this post-2100 GHG are, the closer the 80/50 Plan approaches the Fair Plan. Moreover, GHG emissions need not be reduced by $80 \%$ during the 30 -year period (2020 to 2050) to keep GW below the UNFCCC limit of $2^{\circ} \mathrm{C}\left(3.6^{\circ} \mathrm{F}\right)$. This can be achieved much more slowly by adopting the Fair Plan rather than the 80/50 Plan, as the Fair Plan is designed to phase out GHG emissions over the longest possible time period in the 21 st century, consistent with not exceeding the UNFCCC limit. Of course, if humanity wants to reduce GHG emissions more rapidly than necessary to not exceed the UNFCCC limit, then so be it. But it 

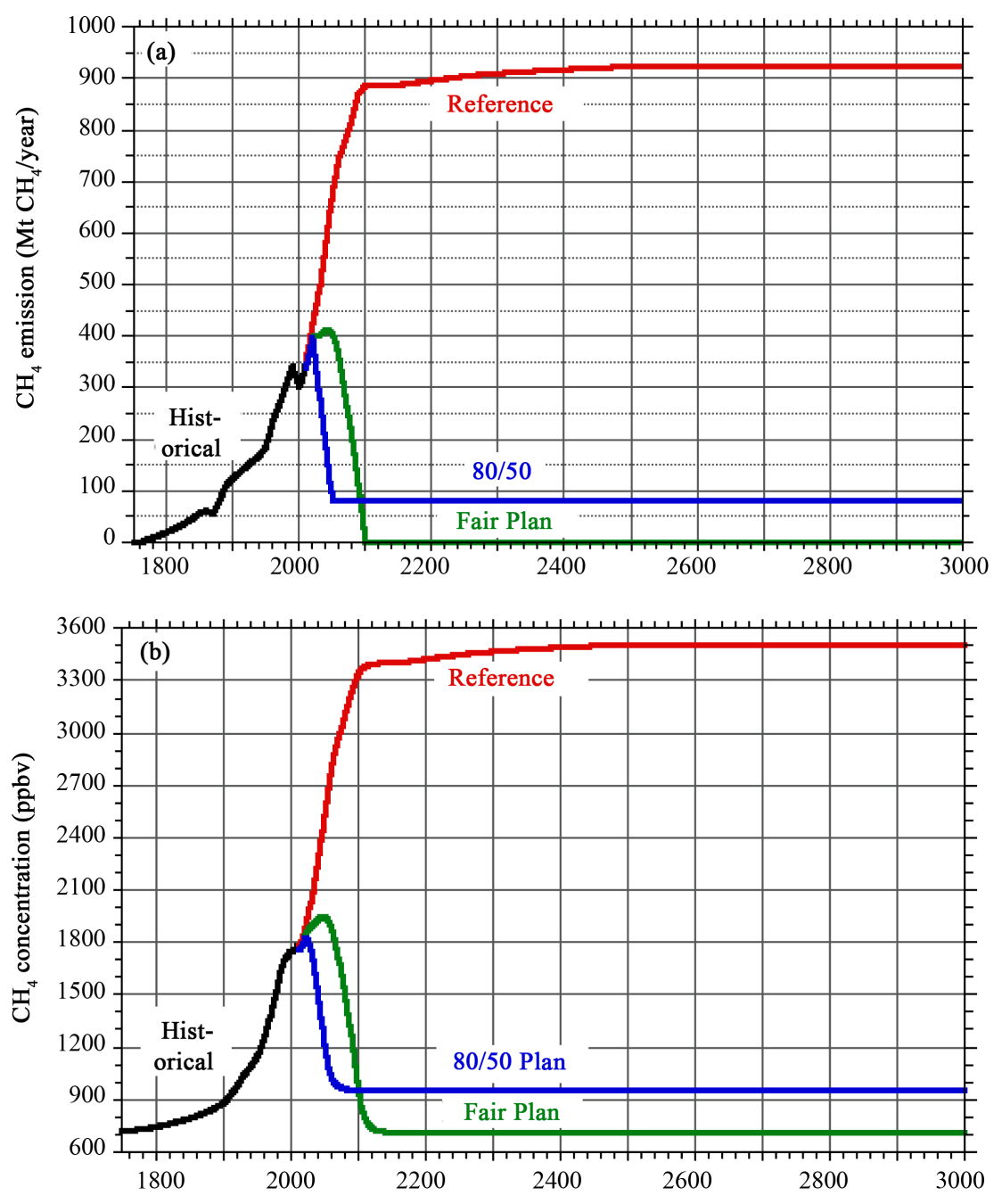

Figure 7. $\mathrm{CH}_{4}$ emission (panel (a)) and concentration (panel (b)) from 1750 through 3000: Historical (black line), Reference case (red line), Fair Plan to Safeguard Earth's Climate (green line), and the 80/50 Plan (blue line).

is likely that doing so will be more costly and more disruptive of society than achieving this objective by the Fair Plan. It is humanity's choice of how to safeguard Earth's climate: the 80/50 Plan or the Fair Plan.

\section{References}

[1] Schlesinger, M.E., Ring, M.J., Lindner, D., Cross, E. and Prince, V. (2014) Fair Plan 5: A Critical Appraisal of Five Congressional Bills to Reduce US $\mathrm{CO}_{2}$ Emissions. Atmospheric and Climate Sciences, 4, 866-873. www.scirp.org/Journal/PaperInformation.aspx?PaperID=51780\#.VIchH2TF9yQ

[2] Schlesinger, M.E., Ring, M.J. and Cross, E.F. (2012) A Fair Plan to Safeguard Earth's Climate. Journal of Environmental Protection, 3, 455-461. www.scirp.org/journal/PaperInformation.aspx?paperID=20038

[3] Schlesinger, M.E., Ring, M.J. and Cross, E.F. (2012) A Revised Fair Plan to Safeguard Earth's Climate. Journal of Environmental Protection, 3, 1330-1335. http://www.scirp.org/journal/PaperInformation.aspx?paperID=23864 http://dx.doi.org/10.4236/jep.2012.310151

[4] Schlesinger, M.E., Lindner, D., Ring, M.J. and Cross, E. (2013) A Fair Plan to Safeguard Earth's Climate: 3. Outlook for Global Temperature Change Throughout the 21st Century. Journal of Environmental Protection, 4, 653-664. www.scirp.org/journal/Paperinformation.aspx?PaperID=33421

[5] Schlesinger, M.E., Ring, M.J., Lindner, D., Cross, E. and Prince, V. (2014) Fair Plan 4: Safeguarding the Climate of "This Island Earth". Atmospheric and Climate Sciences, 4, 431-436. 
www.scirp.org/journal/PaperInformation.aspx?PaperID=48168\#.VI3K5mTF9yQ

[6] Riahi, K., Gruebler, A. and Nakicenovic, N. (2007) Scenarios of Long-Term Socio-Economic and Environmental Development under Climate Stabilization. Technological Forecasting and Social Change, 74, 887-935. http://dx.doi.org/10.1016/j.techfore.2006.05.026

[7] Keigwin, L.D., Sachs, J.P., Rosenthal, Y. and Boyle, E.A. (2005) The 8200 Year B.P. Event in the Slope Water System, Western Subpolar North Atlantic. Paleoceanography, 20, PA2003. http://dx.doi.org/10.1029/2004PA001074

[8] United Nations (1992) United Nations Framework Convention on Climate Change. http://unfccc.int/resource/docs/convkp/conveng.pdf.

[9] Van Hollen, J.C. (2014) Healthy Climate and Family Security Act of 2014, in H.R.5271. U.S. House of Representatives, Washington DC.

[10] Meinshausen, M., et al. (2011) The RCP Greenhouse Gas Concentrations and their Extension from 1765 to 2500. Climatic Change, 109, 213-241. http://dx.doi.org/10.1007/s10584-011-0156-Z

[11] Alfsen, K.H. and Berntsen, T. (1999) An Efficient and Accurate Carbon Cycle Model for Use in Simple Climate Models. CICERO, Oslo, 14.

[12] Alley, R.B., Clark, P.U., Huybrechts, P. and Joughin, I. (2005) Ice-Sheet and Sea-Level Changes. Science, 310, 456460. http://dx.doi.org/10.1126/science.1114613

[13] National Geographic (2014) If All the Ice Melted: Explore the World's New Coastlines If Sea Level Rises 216 Feet. http://ngm.nationalgeographic.com/2013/09/rising-seas/if-ice-melted-map

[14] Fuglesvedt, J.S. and Berntsen, T. (1999) A Simple Model for Scenario Studies of Changes in Climate. Version 1.0, CICERO: Oslo, 59.

[15] Schlesinger, M.E., Andronova, N.G., Entwistle, B., Ghanem, A., Ramankutty, N., Wang, W. and Yang, F. (1997) Modeling and Simulation of Climate and Climate Change, in Past and Present Variability of the Solar-Terrestrial System: Measurement, Data Analysis and Theoretical Models. In: Cini Castagnoli, G. and Provenzale, A., Eds., Proceedings of the International School of Physics "Enrico Fermi" CXXXIII, IOS Press, Amsterdam, 389-429.

[16] Ring, M.J., Lindner, D., Cross, E.F. and Schlesinger, M.E. (2012) Causes of the Global Warming Observed Since the 19th Century. Atmospheric and Climate Sciences, 2, 401-415. http://dx.doi.org/10.4236/acs.2012.24035

[17] IPCC (2007) Climate Change 2007-The Physical Science Basis, Contribution of Working Group I to the Fourth Assessment Report of the IPCC. Cambridge University Press, Cambridge. 